\title{
A Comparison between Ancient Greek and Chinese Philosophy on Politics
}

\author{
Qihan Long1, a \\ ${ }^{1}$ BA History, Royal Holloway University of London, Surrey, TW20 0EX, England \\ ${ }^{\mathrm{a} e m a i l}$
}

Keywords: Ancient Greek philosophy, Chinese philosophy, Politics

\begin{abstract}
Although being two opposite ends of the Eurasian continent, the Greek and Chinese philosophers in the period of $600 \mathrm{BC}$ to $300 \mathrm{BC}$ came with some similar cures for the government. Both Greek and Chinese philosophers emphasized the importance of harmony, virtue and music in politics. Furthermore, in regard to the differences between ancient Greek and ancient Chinese philosophies on politics, it is interesting to note that Aristotle described democracy as the most tolerable one of three perverted form of government. Despite the fact that ancient China never truly formed an aristocracy nor a constitutional political entity, the ideas of Western and Eastern philosophers resonated with each other and formed the brightest light in the human history.
\end{abstract}

\section{Introduction}

From $600 \mathrm{BC}$ to $300 \mathrm{BC}$, it was a golden age for philosophy. Ideas and thoughts were formed in different areas in the world. During this period, great philosophers appeared from Greece in the west to China in the east. In the west, the most prominent philosophers were Socrates, Plato and Aristotle, while in the east, the great philosophers, such as Lao Zi, Confucius and Han Fei accomplished their works in China. Most of the philosophers in that period addressed the ideal form of government and how to rule a state. In almost every revolution, there were the collisions of thought, ideas and knowledge. This essay will secondly evaluate the political thought of ancient Greek and Chinese philosophers. In order to understand the similarities and differences between ancient Greek and Chinese philosophies, one need to understand the essence or principles of those philosophies. This essay will start with Socrates by examining his philosophy on state governing. Since Socrates left no written book, one has to identify his thought through varying portraits drawn by each of his students and critics. we will mention the portraits of Socrates by Plato in his Republic. In other words, this essay will focus on Plato's Socrates.

\section{A Comparison between Ancient Greek and Chinese Philosophy on Politics}

Socrates identified the kind of knowledge that is useful for state governing as the Guardians' knowledge, which could benefit the state both internally and externally. Following his method of inquiry, Socrates stated that people could judge well not because of ignorance, but because of knowledge; however, not all kinds of knowledge are useful for governing the state. For example, the knowledge of farming merely makes it good at agriculture. Since there are more metal-workers than Guardians within the state, according to Socrates "so the state founded on natural principles is wise as a whole in virtue of the knowledge inherent in its smallest constituent part or class, which exercises authority over the rest". The Guardian class could be interpreted as the ruling class. The Guardian class, together with Auxiliaries, which discharge the orders from the ruling class, form the governing body.

In Socrates' perspective, both the individual and the state need to be justified for their well function. Socrates argued that "a state was just when its three natural constituent were each doing their job, and that it was self-disciplined, brave and wise in virtue of certain other states and dispositions of those constituents". Apart from courage and wisdom, self-discipline is one virtue that Socrates valued the most for the well function of the state. He described the virtue of self-discipline as 
"one that produces a harmony between its strongest and weakest and middle elements, whether you measure by the standard of intelligence, or of strength, or of numbers of money. And so we are quite justified in regarding self-discipline as this unanimity in which there is a natural concordance between higher and lower about which of them is to rule in state and individual". Indeed, Socrates valued the virtue of self-discipline, which prevents the strong from plundering the weak, as the virtue to maintain harmony within the society. The virtues of courage, wisdom and self-discipline are needed for the well function of both the state and individual. For the state, self-discipline is the virtue to maintain social stability, harmony and order. For the individual, it is the virtue to bring spiritual harmony within oneself.

Socrates described the ideal form of government as the government ruled by the philosopher like monarch. In order to understand this form of government, one needs to understand how does Socrates define the philosopher: as "those who love to see the truth". He described the passion of a philosopher as the passion for wisdom of every kind without distinction. But, what does it mean by seeing the truth? Socrates provided an explanation: "those who love looking and listening are delighted by beautiful sounds, colours, shapes and the works of art which make use of them, but their mind are incapable of seeing and delighting in the essential nature of beauty itself". In other words, those who are simply delighted by the appearance of beautiful things would not be considered as philosophers. A philosopher should be able to understand the essence of beauty beyond its appearance. Socrates described the status between ignorance and knowledge as 'opinion', which corresponds with the one who is only delighted by the appearance of beauty. Only those who have eyes for the eternal unchanging things should be considered as having knowledge, namely philosophers.

Moving on to Plato's student, Aristotle, he divided the forms of government into three true forms: kingly rule, aristocracy with constitutional government, and three corresponding perversions: tyranny, oligarchy and democracy. Among his true forms of government, Aristotle explained that "the people who are by nature capable of producing a race superior in virtue and political talent are fitted for kingly government; the people submitting to be ruled as freemen by men those virtue renders them capable of political command are adapted for an aristocracy; while the people who are able to rule and to obey in turn by law are suited for constitutional freedom". Aristotle explained what kind of society suit for each true form of governing body.

The political form of monarchy, it involves a government of one, who is pre-eminent in virtue. Under such circumstance, that particular individual ought not be a subject to the state. Aristotle used the metaphor of men claiming to rule over Zeus on the principle of rotation of office to justify the legitimacy of that particular individual as a king. The kingly office is irresponsible and perpetual. There are five kinds of monarchy according to Aristotle. The first one is a generalship for life. Under such form of government, the king could be both hereditary and elective. The second one resembles tyranny. which is common among the barbarians. Under such form of government, the people are by nature slaves. The third one is called Aesymnetia, which existed in ancient Hellas. It is an elective tyranny. The fourth one existed in heroic times. It is a kind of monarchy that rule over voluntary subjects. The fifth form of kingly rule corresponds to the control of a household. It has the disposal of public property. The kingly government is justified when "a whole family, or some individual, happens to be pre-eminent in virtue as to surpass all others".

The second form of government is aristocracy, which could also be called the government of the best. this is a government formed of the best men absolutely. Under this form of government, magistrates are chosen according to their wealth and merit. Aristocracy could be considered as a kind of oligarchy, as being the rule of a few, while constitutional government could be considered as a form of democracy. Democracy is a form of government in which great number are sovereign, while oligarchy is a form in which a few are sovereign; democracy is the form of government in which the free are rulers, and oligarchy in which the rich rule.

The forms of democracy is strictly based on equality. The nature of a democratic state is liberty: "one principle of liberty is for all to rule and be ruled in turn, and indeed democratic justice is the application of numerical not proportionate equality". Under such system every citizen must have equality, and therefore the poor have more power than the rich, because there are more of them and 
the will of majority is supreme. Thus, the will of the majority must be approved. Also, a man should live as he likes. Democracy might also evolve into an extreme form. It happens when people are no longer under the control of law. They would exercise a despotic rule over better citizens. Under such circumstance, the majority become a tyrant, and is many in one. This kind of democracy is led by demagogues: "the demagogues make the decree of the people override the laws, and refer all things to the popular assembly". Democracy might also provoke ostracism in which "equality is above all things, and therefore they ostracise and banish from the city for a time whoever seems to predominate too much through their wealth, or the number of their friends, or through any other political influence". Aristotle used a metaphor to describe this kind of situation: "the lion said to the hares 'where are your claws?', when in the council of the beasts, the later began haranguing and claiming equality for all". In other words, ostracism acts by disabling and banishing the most prominent citizens.

Despite the possible danger within a democratic system, Aristotle still described it as the most tolerable one among the three perversions. Indeed, comparing with the destructive outcome of a tyranny, the danger of democracy is relatively smaller to society. Even compared with oligarchy, the weaknesses of democracy are still more tolerable.

Among the ancient Chinese philosophers, Lao Zi, who was the founder of Daoism , probably produced the most profound philosophy in the period between $600 \mathrm{BC}$ and $300 \mathrm{BC}$. There was a legend recording the conversation between Confucius and Laozi. Confucius once asked Lao Zi, the founder of Daoist philosophy, the reason for chaos, in order to seek for the cure of the society. Laozi replied "the heaven and earth function well without pushing. Sun and moon shine brightly without igniting. Stars are in the order without forcing. Everything is the masterpiece of the nature. If the kings follow the Dao of nature, their kingdoms shall flourish, and vice versa". when the students of Confucius asked him about how is Lao $\mathrm{Zi}$ as a person, Confucius replied "I know fish can swim, birds can fly and beasts can walk; however, as for dragons, I do not know what they are capable of doing. They can ascend to the heaven with the wind. I view Lao $\mathrm{Zi}$ as a dragon because his wisdom is unfathomable".

So, what is the Dao or 'the way'? In the beginning of Tao Te Ching, Lao Zi stated, "the way that can be spoken of is not the constant way; the name that can be named is not the constant name. The nameless was the beginning of heaven and earth; the named was the mother of myriad creatures". When people try to define the Dao, they could only get a fraction of it, since the Dao is constantly changing (though the essence of Dao does not change). The Dao could be described as the way of the universe or the rule of the universe. As Lao $\mathrm{Zi}$ said "the way begets one; one begets two; two begets three; three begets the myriad creatures". This statement of creation resembles the 'big bang' theory. The Dao is formless, but it can be put to use without being exhausted, it is deep and just like the origin of all creatures. It existed even before the god. In other words, the Dao is formed before heaven and earth. It is the only thing that does not change with the time.

Although Lao Zi did not directly talk about the different forms of government, he praised the greatness of the king in his Tao Te Ching. In chapter 25, Lao Zi wrote, "hence the way is great; heaven is great; earth is great; and the king is also great. Within the realm there are four things that are great, and the king counts as one". Therefore, one could argue that Lao Zi regarded kingly rule as the ideal form of government. There are also some guiding principles which teach monarchies how to rule a state in Tao Te Ching. For instance, "the way never acts yet nothing is left undone. Should lords and princes be able to hold fast to it, the myriad creatures will be transformed of their own accord. After they are transformed, should desire raise its head, I shall press it down with the weight of the nameless block. The block is but freedom from desire, and if I (the king) cease to desire and remain still, the empire will be at peace of its own accord". This chapter requires the king to rule the state according to the principle of Dao. It states if the king was free from desires and keep himself mentally peaceful, he shall govern the state very successfully.

Confucianism, too, supported the kingly regime. In one of the classic books of Confucianism, The Book of Poetry, there is a quote which states "every land underneath the heaven belong to the king, and every individual on the land of the king are the subordinates of the king". The ideal king in 
Confucius' words, however, the king who possesses great virtues. Confucius described the reign of a virtuous king as "to rule by virtue is like the way the North Star rules, standing in its place with all the other stars revolving around it and paying court to it".

Aristotle divided the forms of government into three true forms: kingly rule, aristocracy and constitutional government, and three corresponding perversions: tyranny, oligarchy and democracy. In contrast, Confucius only talked about one ideal form of government, the reign of sage, or the reign of a virtuous monarch. Unlike the Mediterranean region, ancient China never truly formed an aristocracy nor a constitutional political entity. This might be one of the reasons for Confucius to only talk about the reign of a virtuous monarch, which Aristotle also considered as a true form of government. Aristotle divided monarchy into five types. Among those types, the fifth form of kingly rule corresponds to the control of a household. It has the disposal of public property. this resembles to the ideal form of kingship proposed by Confucius the most. Confucius responded to the question of how to govern a state of Duke Jing of Qi by "let the ruler be a ruler, the subject be a subject, a father be a father, a son be a son". He compared the ruler as a father and the subject as a son. Therefore governing a state would resemble to managing a household, and the king would consequently have the power to dispose all the properties.

Although being the cradle of democracy, Athens had a long period of myth and history about kingship. The figure of the king provided a powerful image in Greek myth and literature. Sometimes, the king was considered as super-citizen and holder of a superior understanding of the polis. Theseus, the king who united the city and was thus central to Athenian cult and festivals, was the predominant mythical figure, while "king-lists served as a way to connect with the distant past, narratives of the mythical deeds of the founder kings, retold using the generic features of historical narratives, could be used to provide exemplars of good citizenship and personal virtue." In other words, the virtuous kings served as the role model for Athenian citizens.

Confucianism did not become the leading philosophy in Chinese politics until the Han dynasty (206 BC-220 AD), widely considered to be the golden age of China. In the early period of the Han Empire, Emperor Wu adopted the proposal of a Confucianist, Dong Zhongshu (179-104 BC) to use Confucianism as the guiding philosophy to manage the country. Thus, Confucianism became an unalienable part of life for the people in East Asia. Dong's proposal of the three strategies based on the Mandate of Heaven connected the fortune of a state with the mandate of heaven. In another words, if the emperor managed the state with his deep understanding of the Dao of heaven, or the way of heaven, his state shall become prosperous and will flourish. If the emperor did not follow the way of heaven, the descend natural disasters to warn the emperor. If the emperor continuously governed his state with his desires, his regime shall be perished. Dong stated "the origin of the way of the king is based on virtues. Virtues are inferior to the king. The king is inferior to the Spring. Since, Spring is the deed of the heaven, and virtues are the deed of the king. The king should imitate the deed of the heaven and act virtuously accordingly".

In the political structure of Confucianism, the way to prevent the corruption of power is through the self-discipline of the monarch. Similarly, Socrates praised the virtue of self-discipline on the basis that it created harmony amongst all levels of society regardless of whether it is done according to levels of intelligence, strength, or income. Furthermore, self-discipline encourages orderly rule as it encourages higher and lower strata of society to know their place and who should rule in both state and daily life. In fact, the reason that Dong Zhongshu asked Emperor Wu to imitate spring, the deed of heaven, was to reflect the harmony existed in the nature to the harmony that ought to be in the society. The means to achieve this kind of harmony was through self-discipline, indicating an area where ancient Greek and Chinese philosophies overlap.

Both Aristotle and Confucius emphasized the importance of harmony in the good function of society and the individual. Aristotle stated "there seems to be in us a sort of affinity to harmonies and rhythms, which make some philosophers say the soul is a harmony, others, that she possesses harmony". Confucius commented the flying dragon in the heaven in the first chapter of I Ching as, "Things that accord in tone vibrate together. Things that have affinity in their inmost natures seek one 
another. Water flows to what is wet, fire turns to what is dry. Clouds (the breath of heaven) follow the dragon, wind (the breath of earth) follows the tiger. Thus the sage arises, and all creatures follow him with their eyes. What is born of heaven feels related to what is above. What is born of earth feels related to what is below. Each follows its kind". As an individual, only if one's mind harmonize with one's soul, one could improve and cultivate oneself. As the society, only if different classes harmonize with each other, the society could guarantee its good function.

Aristotle describes virtue as the source of happiness. He argued that the soul is more noble than the body. Thus, the wise man should choose the external goods for the sake of the soul, and not the soul for the sake of the external goods. Confucius explained the virtue of ren (仁, mercy or humaneness) as "do not impose on others what you do not desire for yourself" . Both Aristotle and Confucius valued virtue highly in the state governing. Both philosophers agreed that people must play different roles and functions in the state and both maintain that the aim of governance is to make people virtuous, as virtuous men make the best rulers.

\section{Conclusions}

In conclusion, although being two opposite ends of the Eurasian continent, the Greek and Chinese philosophers in the period of $600 \mathrm{BC}$ to $300 \mathrm{BC}$ came with some similar cures for the government. For example, the philosopher described in The Republic resembles to the sage portrayed in Tao Te Ching. Both Greek and Chinese philosophers emphasized the importance of harmony, virtue and music in politics. Furthermore, in regard to the differences between ancient Greek and ancient Chinese philosophies on politics, it is interesting to note that Aristotle described democracy as the most tolerable one of three perverted form of government. However, the Chinese philosophers never took that approach. They mainly focused on the perfect form of political entity. Unlike the Mediterranean region, ancient China never truly formed an aristocracy nor a constitutional political entity. This may be one of the reasons why Chinese philosophers only talk about the reign of a virtuous monarch. But despite the fact that ancient China never truly formed an aristocracy nor a constitutional political entity, the ideas of Western and Eastern philosophers resonated with each other and formed the brightest light in the human history.

\section{References}

[1] Zhang Siqi. On the Agreement Between Confucius'Qi with the Ancient Greek Thoughts [J]. Journal of Yantai University (Philosophy and Social Science Edition), 2016, 29(1): 1-14.

[2] Zhang Wanmin. The Writing and Oral Transmission of The Book of Odes in Early China: The Recent Dispute in the Western Sinological Circles and Its Background [J]. Journal of Peking University (Philosophy and Social Sciences), 2017, 54(6): 80-93.

[3] Zheng Kai. Ontology and Metaphysics in Chinese Philosophy [J]. Philosophical Researches, 2018(1): 77-85+128.

[4] Wang Xiaochao. Research on Later Greek Philosophy in Chinese Academic Circles[J]. Social Sciences in China, 2012, 33(3): 19-30. 